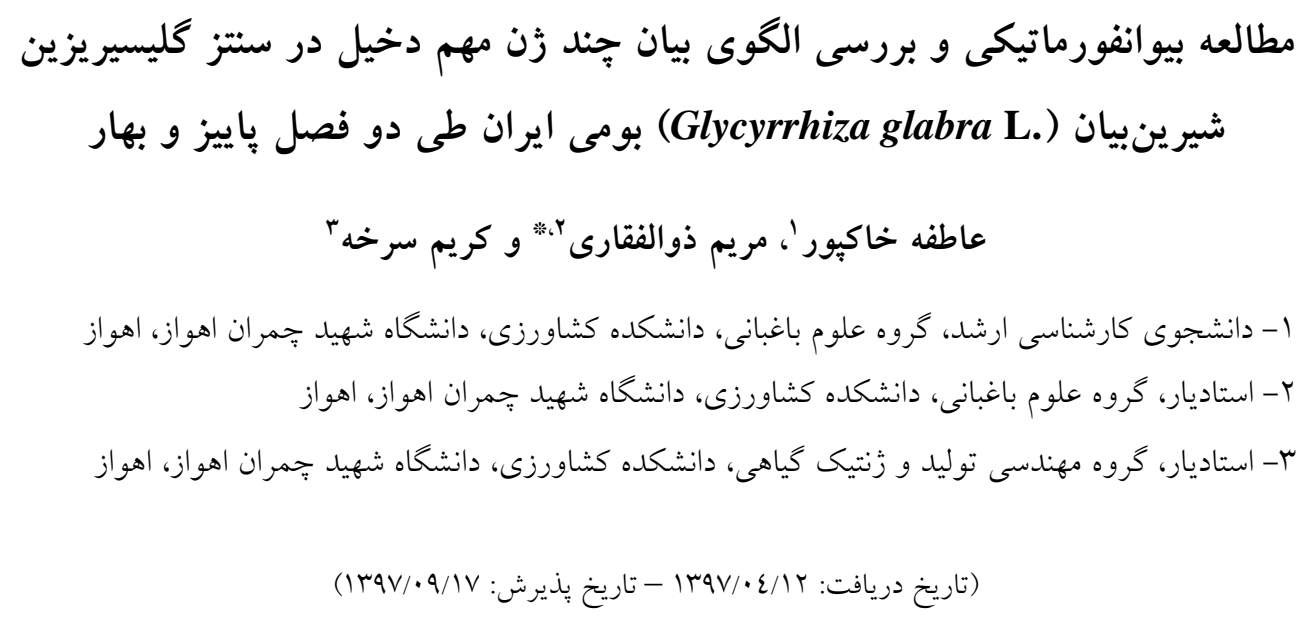

شيرينبيان يكى از كياهان دارويى با ارزش و در معرض انقراض است. شناسايى و معرفى تودهايى كه ماده مؤثره كليسيريزين

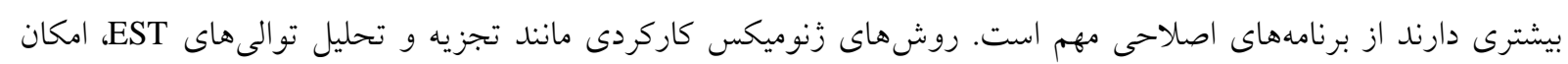

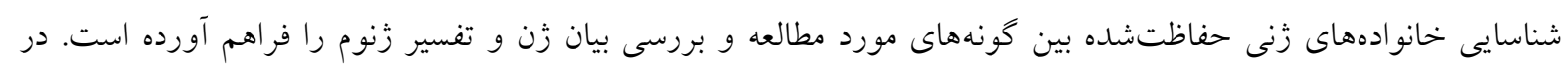

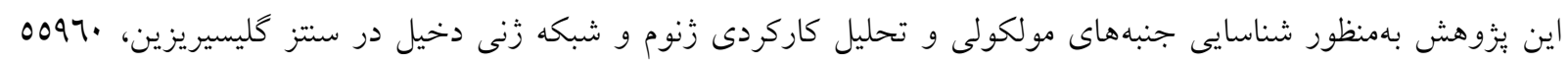

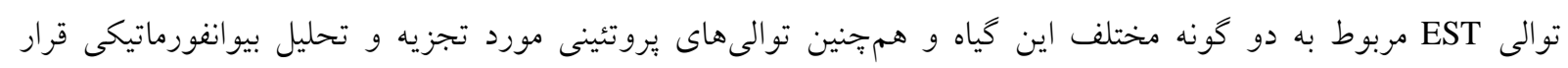

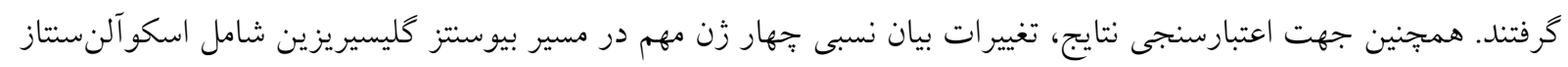

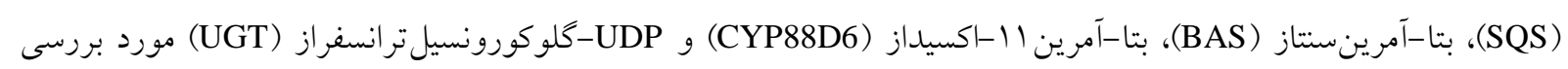

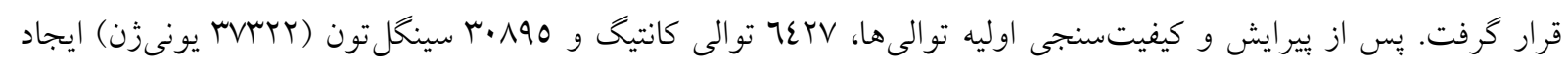

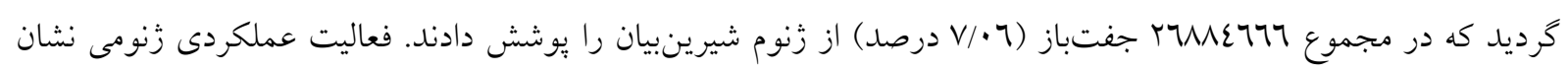

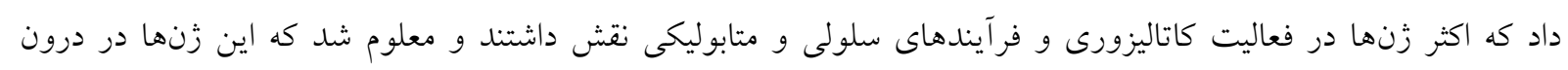

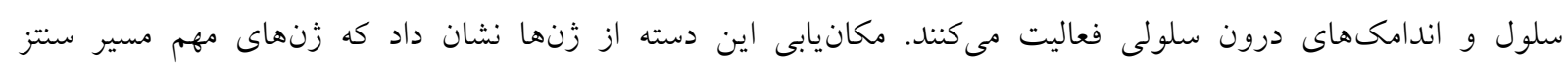

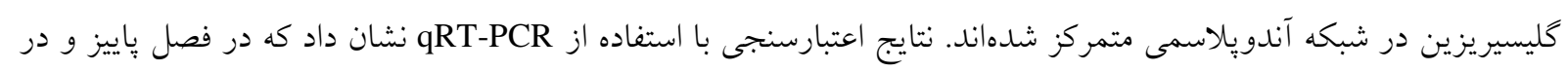

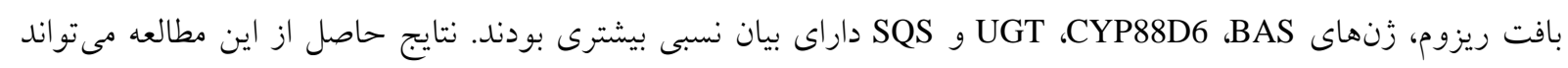

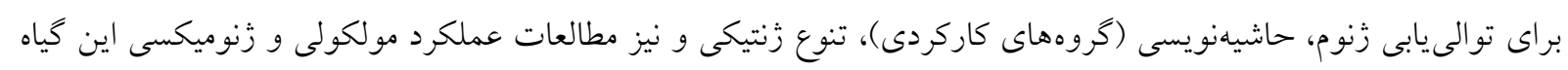
ارزشمند باشد.

واز كان كليدى: زنوم كاركردى، شبكه زنى، شيرينبيان، كليسيريزين، qRT-PCR 
oxidosqualene آنزيمهايى كه در سنتز كليسيريزين نقش دارد بتا-

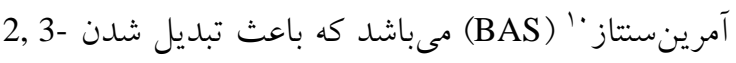

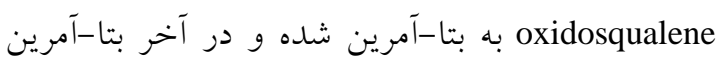

توسط آنزيمهاى سيتوكروم CYP88D6) "P450s و تبديل به اسيد كليسيرينيك شده و در انتها

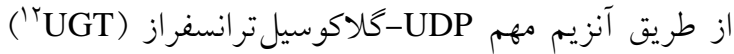

$$
\text { به كليسيريزين تبديل مى شود. }
$$

بررسى هاى بيوانفورماتيكى ساختار اسيدنوكلئى و و يروتئينها و مقايسه، طبقهبندى و بيشبينى ساختار آنها مىتواند در بيشبينى موقعيت سلولى بروتئين، بازسازى مسيرهاى متابوليكى و شبيهسازى و تحليل عملكردى آنها مؤثر واقع باشد (Zarabi et al., 2013).

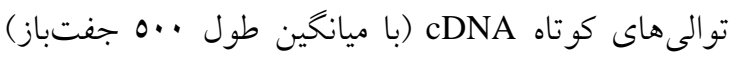

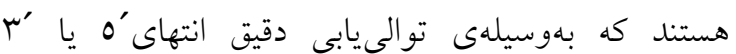
همسانهاى ع' (كلونهاى) cDNA ايجاد مىشوند. كاربرد اوليهى هاEST كشف زن زاست. امّا از كاربردهاى بييجيدهتر آنها مىتوان به شناسايى خانوادههاى زنى حفاظتشده بين گونهاى مورد بررسى، شناسايى كوناگونىهاى ويرايش رونوشت زن و تعيين ساختار زن از طريق ترادفسازى 10 و انطباق رونوشتها، بررسى بيان زن و تفسير زنومجا، شناسايى زنهاى جديد، نقشهيابى زنوم و شناسايى مناطق كدكننده اشاره كرد ( AliAkbari et (al., 2013; Zarabi et al., 2013 و جزئيات مربوط به هركدام را مىتوان از بايخاههاى داده

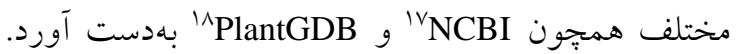
وجود اين منابع غنى از اطلاعات در كنار در دسترس برس بودن سرويسها و نرمافزارهاى مختلف بيو انفورماتيك راه را براى مطالعه و بررسى تغييرات زنومى هموار نموده

است (Ogata and Suzuki, 2011).

10 - $\beta$-amyrin synthase

11- Cytochrome P450

12- UDP-glucosyltransferases

13- Expressed Sequenced Tags

14- Clone

15- Alignment

16- Genome annotation

17- National center for biotechnology information

(https://www.ncbi.nlm.nih.gov)

18- Plant genome database
شيرينبيان متعلق به خانوادهى بقولات (Fabaceae) است كه شامل كونه بومى جنوب ارويا، هندوستان و بخشى از

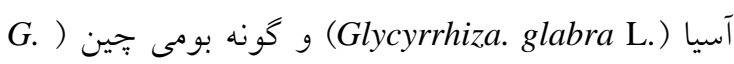
(Rebhun et al., 2015) مىباشد (uralensis F.a سالهاست اين گياه در سراسر دنيا بهعنوان يك گياه دارويى و شيرين كننده طبيعى مورد استفاده قرار مى گيرد. كليسيريزين' ماده اصلى موجود در ريشه و رئ ريزوم شيرينبيان، عامل شيرين شدن اين كياه است كه بهعنوان ماده شيرين كننده در بسيارى از محصولات تجارى استفاده مىشود (Pandey and Ayangla, 2017). علاوهبر كليسيريزين تركيبات فعال ديخرى نيز از قبيل فلاونوئيدها،

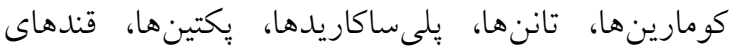

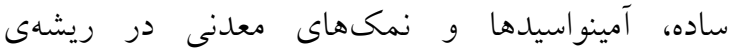
شيرينبيان وجود دارند (Bayati zadeh et al., 2013). از جمله از فلاونيدهاى مهم ريشهى شيرينبيان كوئرستين بَ و كالابريدين ' مى باشد (Fukai et al., 1996). خواص

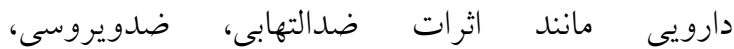
ضدميكروبى، آنتىاكسيدان، ضدآسم و نيز فعاليتهاى ضدسرطانى براى شيرينبيان در نظر گرفته شده است (Hosseinzadeh and Nassiri-Asl, 2015) و تأ به حال داروهاى ضدالتهابى، ضدسرطانى و ضدويروسى از

شيرينبيان ساخته شدهاند (Tang et al., 2015). كُليسيريزين يك ترىترينوئيدع سايونينى ْ مىباشد كه در قسمتهاى جوبى ريشههاى ضخيم شده و ريزوم شيرينبيان وجود دارد (Pandey and Ayangla, 2017). مسير بيشنهادى براى بيوسنتز كليسيريزين و تعيين زنهاى دخيل در اين مسير در شكل ا نشان داده شده است. اين مسير از جرخه اصلى موالونيك اسيدج شروع شده كه در

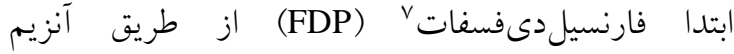
اسكوآلنستناز ^(SQS) به اسكوآلن و در مرحله بعد

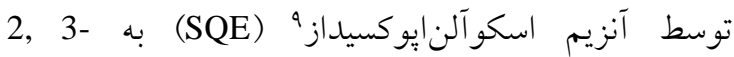

1- Glycyrrhizin

2- Quercetin

3- Glabridin

4- Triterpenoids

5- Saponin

6- Mevalonic acid

7- Farnesyl diphosphate

8- Sequalene synthase

9- Squalene epoxidase 


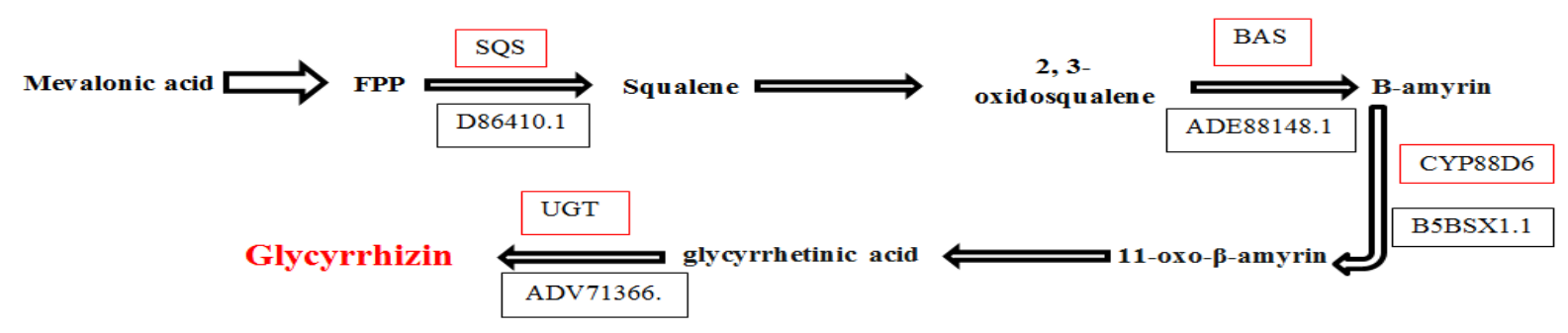

$$
\text { شكل 1- مسير بيوسنتز كليسيريزين }
$$

Figure 1. Glycyrrhizin biosynthesis pathway

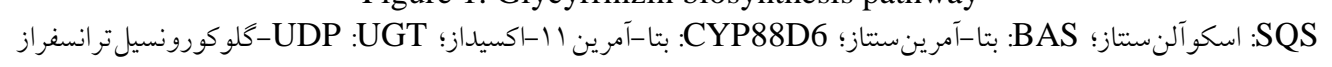

SQS: squalene synthase; BAS: $\beta$-amyrin synthase; CYP88D6: $\beta$-amyrin 11-oxidase; UGT: UDPglucuronosyltransferase

كيفى توالىهاى EST و حذف وكتورها، توالىهاى تكرار

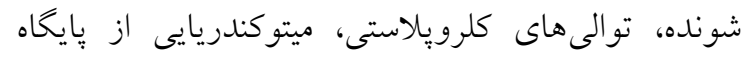

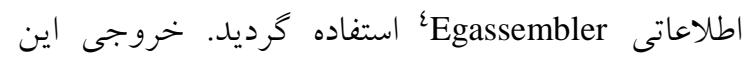
سرويس شامل يك فايل داراى دستههايى با دو يا تعداد

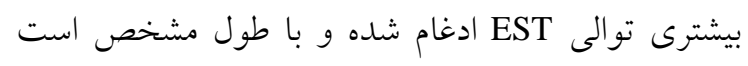

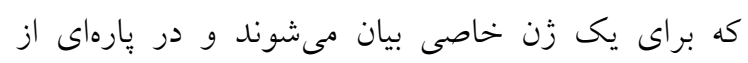

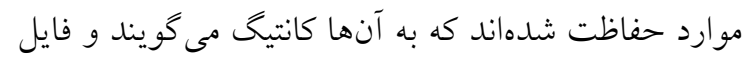

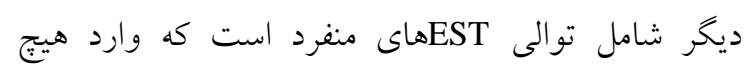

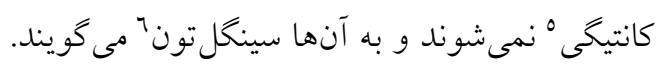

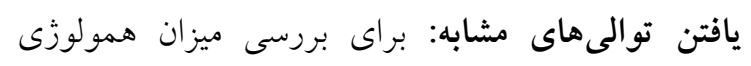
توالىهاى EST مربوط به زنوم شيرينبيان از نرمافزار CLC Genomics Workbench 9

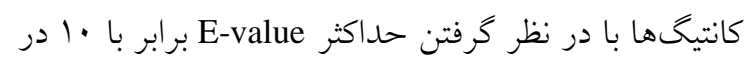

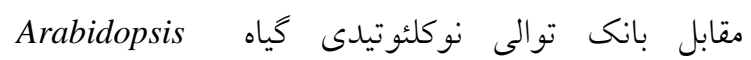
Local Blast بهنوان كياه مرجع بهونئ thaliana

$$
\text { | (1ستفاده شد. }
$$

دريافت توالىهاى بروتئينى: توالىهاى بروتئينى همانند

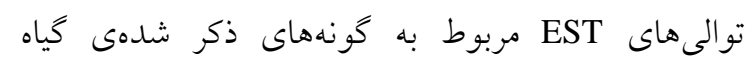

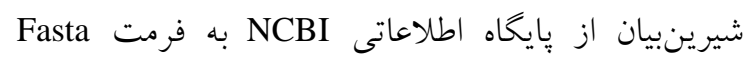

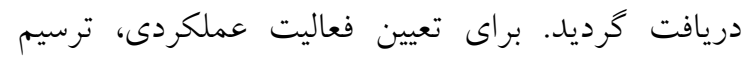

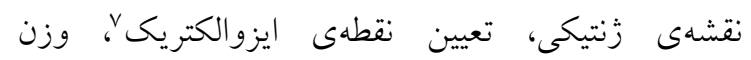

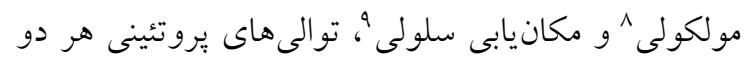

4- http://egassembler.hgs.jp

5- Contig

6- Singleton

7- Isoelectric point

8- Molecular weight

9- Cell location

$$
\begin{aligned}
& \text { با توجه به اهميت نقش سايونينها و نيز كليسيريزين }
\end{aligned}
$$

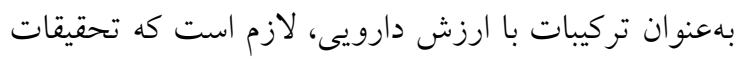

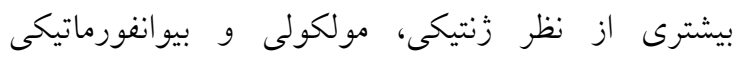

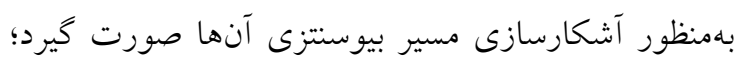

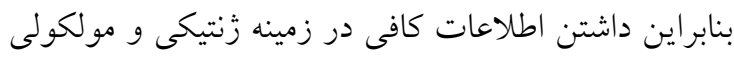

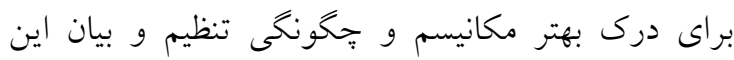

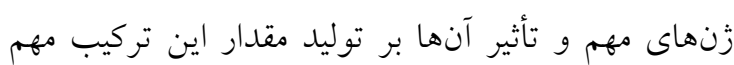

دارويى در شيرينبيان ضرورى به نظر مىرسد ( al., 2011; Mochida et al., 2017; Nasrollahi et al., 2014). هدف از مطالعه حاضر واكاوى كتابخانهاى EST

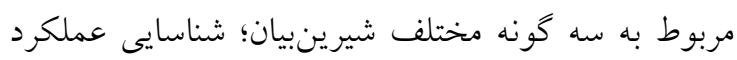

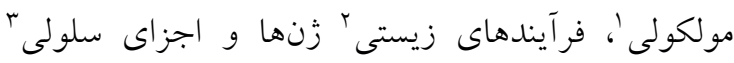

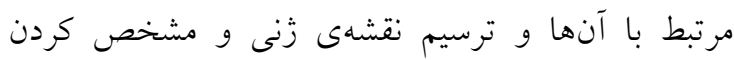

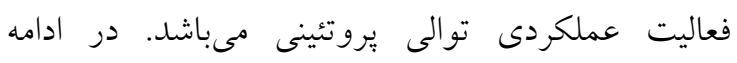

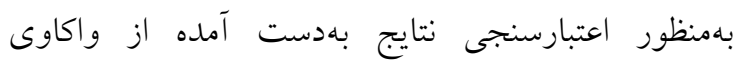

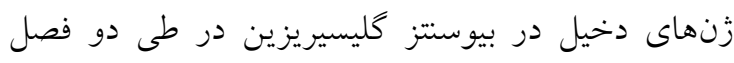

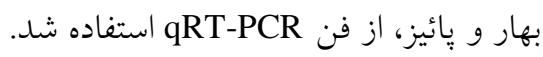

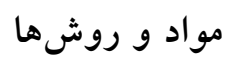

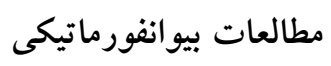
دريافت كتابخانهاى بيانى EST زن زنهاى بيوسنتز كليسيريزين و كيفيتسنجى توالىهاى توالى EST مربوط به كتابخانهى دو كونهى Glycyrrhiza

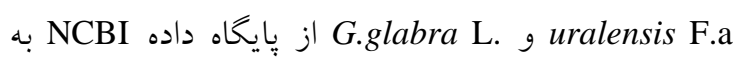
فرمت Fasta دريافت شد. بهمنظور سنجش و ارزيابى بإن داده

1- Molecular function

2- Biological processes

3- Cellular components 
كرديدند. در مرحله بعد عمل سنتز cDNA طبق دستورالعمل كيت prime script RT reagent (تاكارا، زاين) و با استفاده از آغازگرهاى Oligo dt و Random

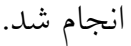

طراحى آغازگرهاى رفت و برگشتى مربوط به زنهاى مهم و زن اكتين جهت آناليز بيان زن: با استفاده از نرمافزار آنلاين Primer آغازگرهاى مرتبط با هريك از زنهاى اسكو آلنسنتاز (SQS) (D86410.1)، بتا-

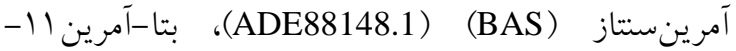
اكسيداز (CYP88D6) ( كلوكورونسيلترانسفراز (UDT) (ADV71366.1) و زن

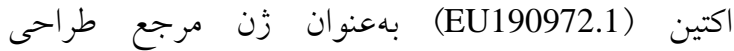
كرديدند. ليست آغازگرها در جدول آآورده شده است. qRT- بررسى ميزان بيان زنها با استفاده از واكنش PCR مقايسه آنها در دو فصل مختلف، از واكنش زنجيرهاى يليمراز در زمان واقعى استفاده شد. اين واكنش با استفاده از مخلوط واكنش تاكارا حاوى SYBR-Green و آغاز گرهاى اختصاصى مرتبط با زنها انجام گرديد. جهت بررسى اختصاصى بودن آغازگرهاى مورد استفاده از نمودار نقطه ذوب در طيف دماى 90 درجه سانتى گراد استفاده شد و به ازاى هر سيكل ب/ • درجه سانتى گراد كم شد تا به دماى .7 درجه سانتى گراد (دماى اتصال آغازگرها) برسد. براى تجزيه و تحليل نتايج از زن اكتين بهاعنوان زن كنترل داخلمى استفاده شد. آناليز نتايج حاصل از qRT-PCR با استفاده از روش معادله تشخيص بيان نسبى هر يك از زنها و نسبت به زن كنترل داخلى مىباشد (Schmittgen and Livak, 2008). آزمون t-test بر روى دادهها براى تشخيص تفاوتها و معنى دار بودن يا نبودن از نظر آمارى، استفاده شد. در نهايت يردازش دادهها و رسم نمودارها با استفاده از نرمافزار Excel نتايج و بحث

4- http://primer3.ut.ee
كونه باهم ادغام كرديدند و توالىهاى اضافى حذف

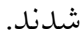
ترسيم نقشهى زنى و مشخص كردن فعاليت عملكردى توالى :بروتئينى: تعيين نقشهزنى براى شناسايى ارتباط بين زنهاى مربوط به كونهاى Glycyrrhiza با استفاده از بايخاه String' در مقابل بانك توالى يروتئينى گياه Arabidopsis thaliana تعيين فعاليت عملكردى توالىها (كه شامل عملكرد مولكولى، فر آيندهاى بيولوزيكى و اجزاى سلولى مى باشد) A. از همين سرويس در مقابل بانكى توالى يروتئينى كياه thaliana

تعيين نقطهى ايزوالكتريك (Pi)، وزن مولكولى (Mw) و مكانيابى سلولى توالىهاى بروتئينى: بهمنظور تعيين

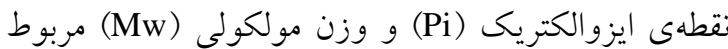
Expasy به توالىهاى يروتئينى از سرويس بيوانفورماتيكى تصنى

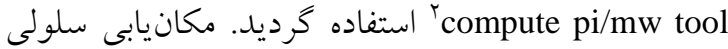
توالى هاى يروتئينى توسط يايخاه softberry انجام كرديد.

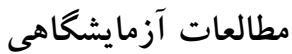
جمع آورى نمونههاى گياهى شيرينبيان، استخراج RNA كل و سنتز CDNA: ريزومها و برگهاى تازه شيرينبيان (Glycyrrhiza glabra) از منطقه منصوريه واقع در شهرستان به.بهان (در ·r درجه و rr دقيقه عرض شمالى و .0 درجه و 17 دقيقه طول شرقى در منتهى اليه جنوب شرقى استان خوزستان و با •بr متر ارتفاع از

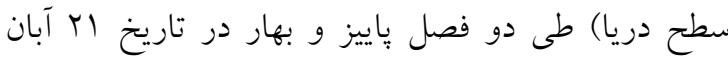
سال زمان استخراج RNA در ازت مايع نحهدارى گرديدند. ro-O. استخراج RNA، توسط ازت مايع يودر كرديدند. استخراج RNA كل از بافتها با استفاده از كيت Biobasic كانادا مطابق دستورالعمل شركت انجام شد. كميت و كيفيت نمونههاى RNA با استفاده از اسبكتروفتومترى بررسى

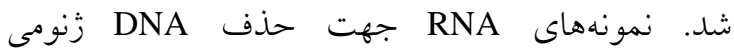
باقى مانده با آنزيم Takara, Ltd., Japan) DNase I تيمار

1- https://string-db.org

2- https://web.expasy.org

3- http://www.softberry.com 
زنهاى قبل و بعد خود در اين مسير ارتباط نزديكترى

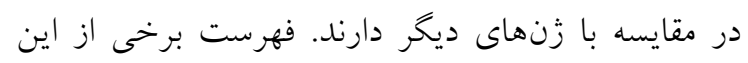

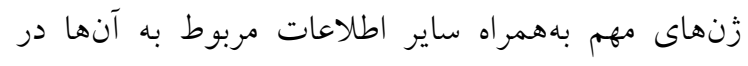

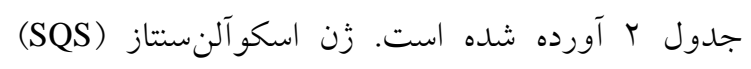

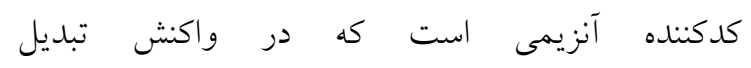
فارنسيلدىفسفات (FDP) (بهعنوان يكى از محصولات

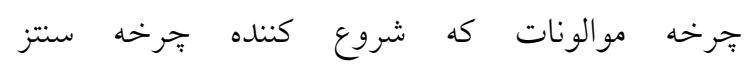

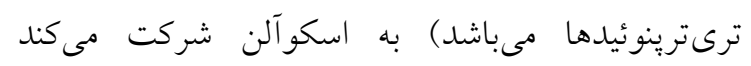
Zhao et al., ) (Shirazi et al., 2017)

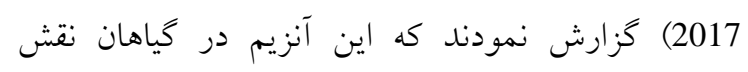
مهمى در تنظيم بيوسنتز فيتواسترولها و ترى ترينوئيدها

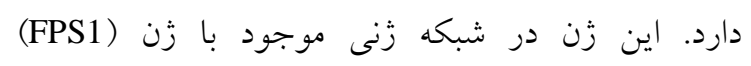

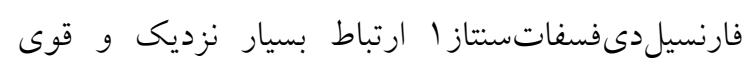

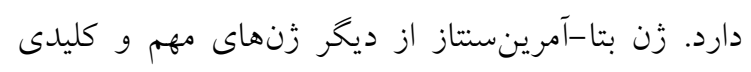

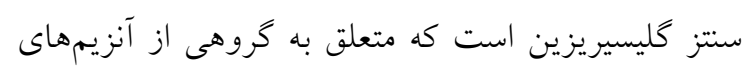

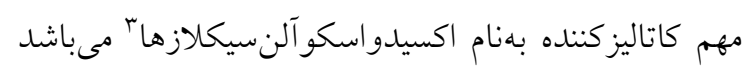
كه در جرخه سنتز (Hossein Panahi et al., 2016) ترىترينوئيدها در واكنش تبديل اكسيدواسكو آلن به بتا-

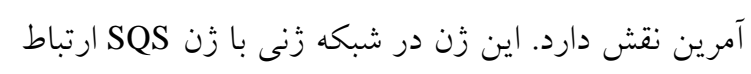
نزديك دارد.

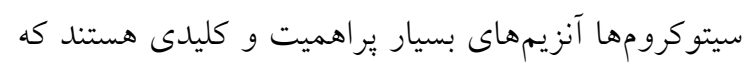

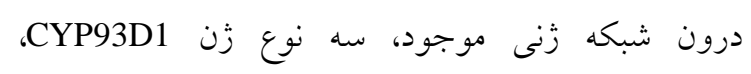
و CYP716A1

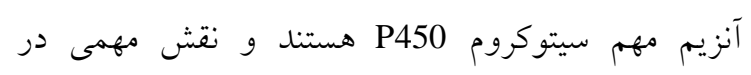

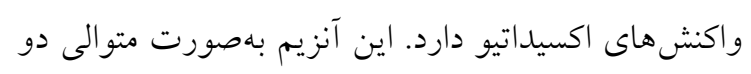

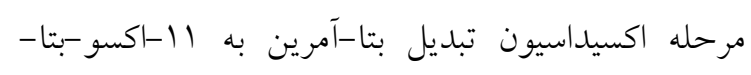

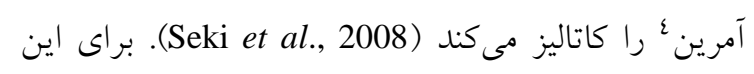

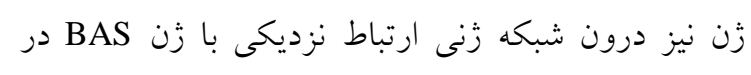

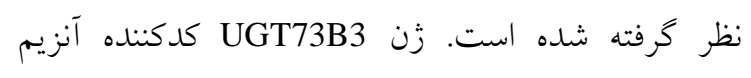
ككلوكزيلترنسفراز است كه در مرحله نهايى توليد كليسيريزين نقش كليدى و اختصاصى ايفا كرده و و اسيدكليسيرينيك را به كليسيريزين تبديل مى كند. UGTs،

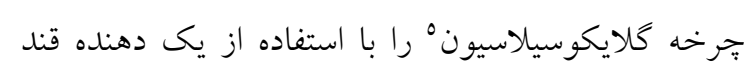

3- Oxidoscoalen cyclase

4- 11- Exo-beta amrin

5- Glycosylation

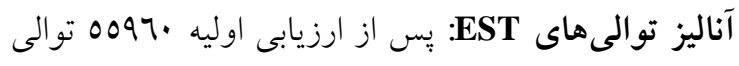
TETV بST

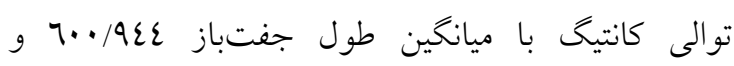

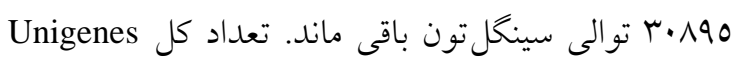

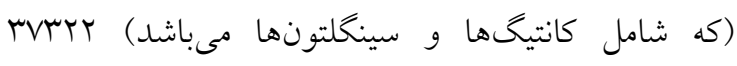

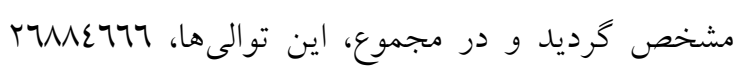

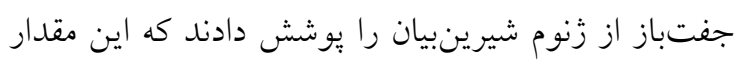

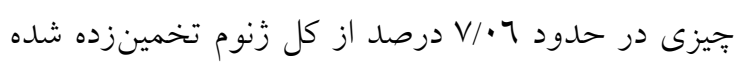

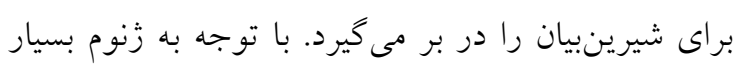

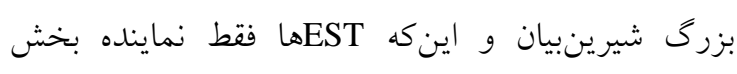

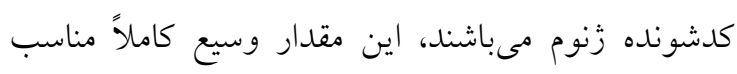
است (جدول r (T).

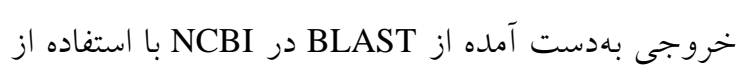

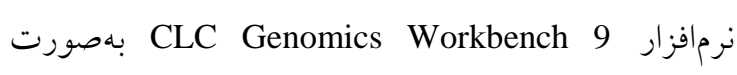
'HSP مىباشد و HSP شامل دو قطعه توالى دلخواه و

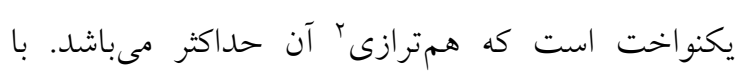

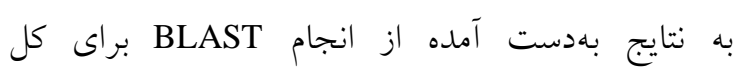

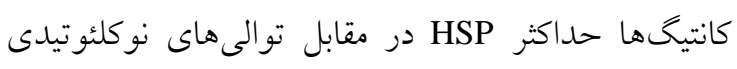

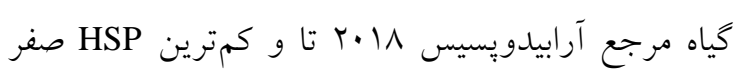

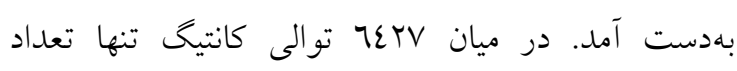

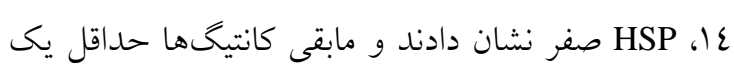
داشتند كه اين بهمعناى داشتن شباهت زياد توالى زنوم

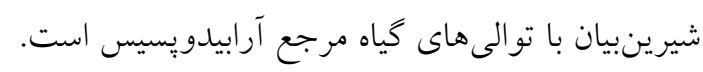
تعيين شبكه زنى مربوط به زنهاى مهم دخيل در سنتز

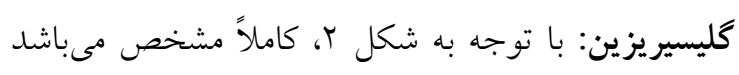

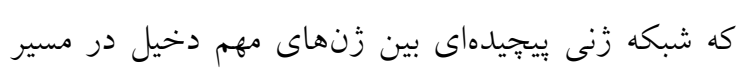

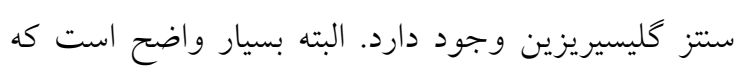

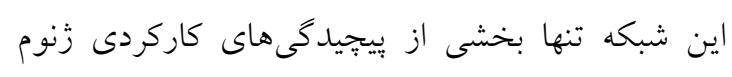

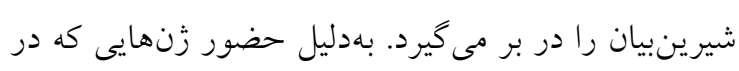
مسير سنتز كليسيريزين هستند، اين بخش بـ بسيار حائز اهميت است. از بين زنهاى دخيل در سنتز كليسيريزين

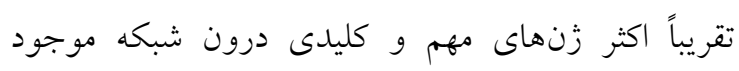

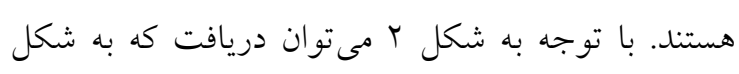

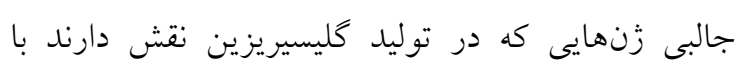

1- High-scoring segment pair

2- Alignment 
خاكيور و همكاران

اجزاى سلولى براى اين زنها در نظر كرفته شده است درون كميلكس سنتز ATP براى منتقل كنندهى يروتون Li et ( است. در يزوهش انجام شده توسط لى و همكاران

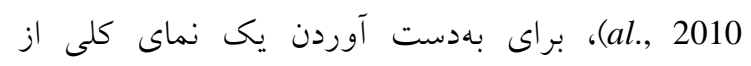
ويز كى هاى زنهاى مربوط به Glycyrrhiza uralensis، با بال توجه به آناليزهاى هستىشناسى زنها، ويزّى هاى زهاى زنهاى دركير و شناخته شده در فرآيندهاى متنوعى قرار كرفتند.

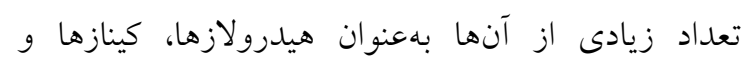
ترانسفرازها شناسايى شدند. بيشترين فعاليت آنها در فرآيند بيولوزيكى مربوط به فرآيندهاى سلولى بود و نيز

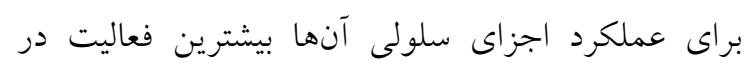

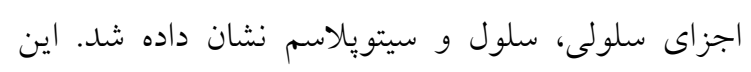

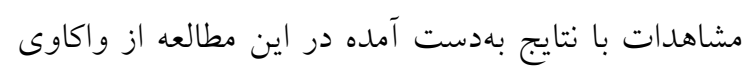
زنهاى دخيل در سنتز كليسيريزين مطابقت دارد.

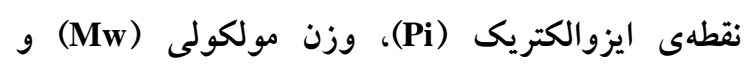
مكانيابى سلولى توالىهاى يروتئينى: جهت تعيين نقطه

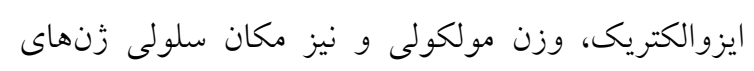

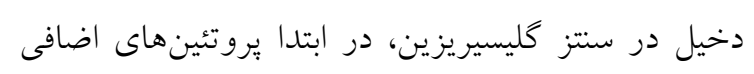
حذف كرديده و همانطور كه در جدول ع و 0 مشاهده مىشود يروتئينهاى مهم مربوط به مسير بيوسنتز

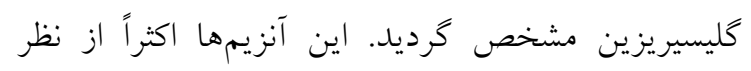
مكان سلولى در شبكه آندويّاسمى ' قرار كرفتهاند. سايونينهاى ترىترينوئيدى در سيتوزول ت توليد مىشوند و با توجه به اينكه كليسيريزين هم نوعى سايونين ترىترينوئيدى است در سيتوزول ساخته شده و جونه بهن تركيبى آبدوست مىباشد براى ذخيره به واكوئل منتقل

مىشود (Wink, 2010). همجينين آنزيمهاى كاتاليزگر در شبكه آندويلاسمى قرار

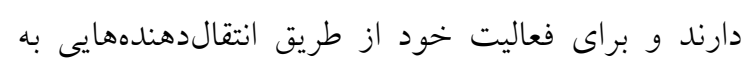
سيتوزول منتقل مىشوند. ديخر آنزيمهاى دخيل در مسير

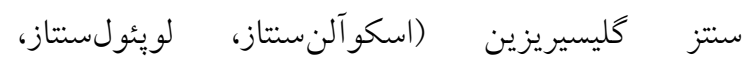

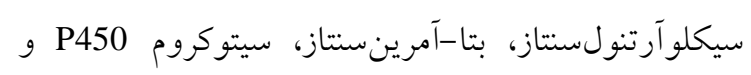
-UDP

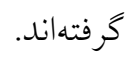

1- Endoplasmic reticulum

2- Cytosol
مطالعه بيوانفورماتيكى و بررسى الكوى بيان جِند زن مهم دخيل ...

مانند UDP-كلوكز، UDP-كالاكتوز، كسيلوز و كلوكورونيكاسيد كاتاليز مى كند. بهنظر مىرسد كه تغييرات در تعداد زنجيرههاى قند، تركيب و موقعيت آنها در ساختار ترىترينوئيدها تأثير زيادى بر انتقال و ذخيره Seki et al., (اخل و خارج سلولى در گياهان دارد 2015). هم جنين اين زن در ياسخهاى دفاعى و تنشى هم

$$
\text { درگير مىشود (جدول س). }
$$

هستى شناسى زن (Gene ontology) و و فعاليت عملكردى توالىهاى مربوط به زنوم شيرينبيان: براى بيشبينى فعاليت عملكردى در ميان توالىهاى يروتئينى مرتبط به زنوم شيرينبيان از يايخاه String استفاده كرديد.

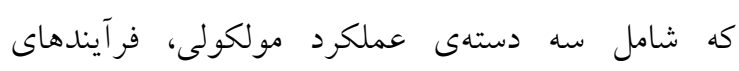
بيولوزيكى و اجزاى سلولى مىباشند (شكل س). همانطور كه در شكل r مشاهده مى شود، اين زنها از نظر عملكرد مولكولى نقش بسيار زيادى در فعاليت كاتاليزورى ايفا مى كنند و نيز بهطور قابلتوجهى در اكسيدوردوكتاز فعاليت دارند. كمترين كاربردى كه براى آنها در نظر نظر كرفته شده است در فعاليت oxidosqualene cyclase است. بيشترين سهم افزايشى براى زنهاى مربوطه در

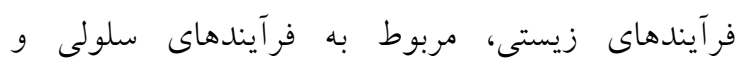

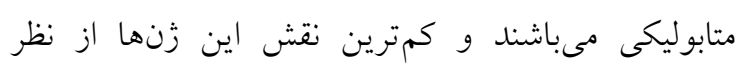
فرآيندهاى زيستى در فسفوريلاسيون اكسيداتيو و فر آيند بيوستتز استيل كو آنزيمA مى فياشد. در مطالعات كيم و همكاران (Kim et al., 2011) نيز كزارش شده است كه در فرآيندهاى بيولوزيكى، زنها در

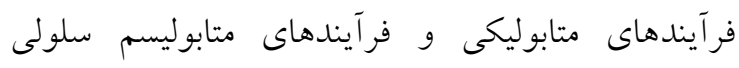
بهطور قابلتوجهى نقش دارند و عملكرد مولكولى زنها بيشتر روى اتصالات بروتئينى و يونها و و فعاليت

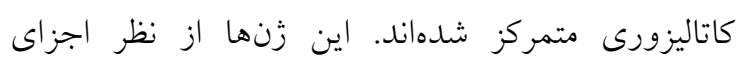
سلولى اكثراً درون سلول و اندامكهاى درون سلولى إنى فعاليت زيادى دارند كه اين را مىتوان با سنتز تركيبات ترىترينوئيدى (كليسيريزين) كه اكثراً توليد آنها در در سيتوزول هست تطبيق داد. آنزيمهاى درگير در اين مسير سنتز از شبكهى آندويلاسمى به سيتوزول منتقل و در آنجا

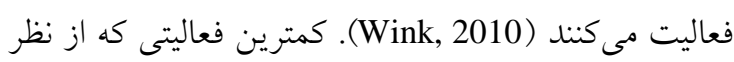


جدول ا - آغازگرهاى رفت و بركشتى طراحى شده مربوط به زنهاى مورد مطالعه و زن اكتين

Table 1. Designed forward and reverse primers for the studied genes and actin gene

\begin{tabular}{|c|c|c|c|}
\hline $\begin{array}{c}\text { نام } \\
\text { Name of primer }\end{array}$ & 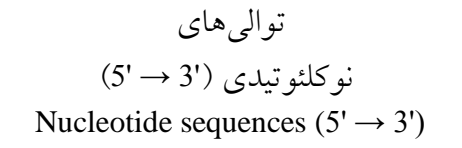 & $\begin{array}{c}\text { |تصال (سانتى گراد) } \\
\text { Annealing temperature }\left({ }^{\circ} \mathrm{C}\right)\end{array}$ & $\begin{array}{c}\text { محصول (جفت انداز) } \\
\text { Product size (bp) }\end{array}$ \\
\hline SQS-forward & GCGAGGTCTAACTGCCAAAG & 60.5 & \multirow{2}{*}{225} \\
\hline SQS- reverse & CCGTTCCCATTCCTCAATAA & 58.4 & \\
\hline bAS-forward & TGCGGACATTGTAGTTGAGC & 58.4 & \multirow{2}{*}{220} \\
\hline bAS- reverse & ACCAAGTGCGAACCAAGAAC & 58.4 & \\
\hline CYP88D6-forward & TCGGCGATCTATTGTCCTTC & 58.4 & \multirow{2}{*}{230} \\
\hline CYP88D6- reverse & GGGTCTACATCGTGCCAACT & 60.5 & \\
\hline UGTs-forward & CCCAACGACTTCAACCTCAT & 58.4 & \multirow{2}{*}{217} \\
\hline UGTs- reverse & ACCCAAGTTTTGTGCTCCAC & 58.4 & \\
\hline Actin-forward & TCCTTCGTCTGGATCTTGCT & 58.4 & \multirow{2}{*}{248} \\
\hline Actin- reverse & GCAACGGAATCTCTCAGCTC & 60.5 & \\
\hline
\end{tabular}

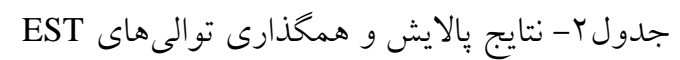

Table 2. Results of ESTs cleaning and assembling

\begin{tabular}{|c|c|c|c|c|c|}
\hline طول كل يوشش داده شده & تعداد كل & تعداد & ميانخين طول تو الى هاى & تعداد & تعداد كل توالى هاى \\
\hline از زنوم (جفتباز) & يونىزنها & سينخلتون & (جفتباز ) كانتيخ & كانتيخ & EST \\
\hline $\begin{array}{l}\text { Total length of the } \\
\text { genome covered (bp) }\end{array}$ & $\begin{array}{c}\text { Total number of } \\
\text { unigenes }\end{array}$ & $\begin{array}{l}\text { Number of } \\
\text { singelton }\end{array}$ & $\begin{array}{c}\text { Average length of contig } \\
\text { sequences (bp) }\end{array}$ & $\begin{array}{c}\text { Number of } \\
\text { contig }\end{array}$ & $\begin{array}{l}\text { Total number of } \\
\text { sequences EST }\end{array}$ \\
\hline 26884666 & 37322 & 30895 & 600.944 & 6427 & 55960 \\
\hline
\end{tabular}

$$
\text { جدول ب- زنهاى مهم مسير سنتز كليسيريزين درون شبكه زن }
$$

Table 3. Important genes for synthesis of glycyrrhizin within the gene network

\begin{tabular}{|c|c|c|}
\hline كره & 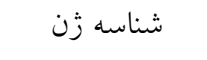 & 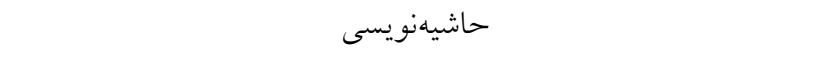 \\
\hline Node & Gene ID & Annotation \\
\hline BAS & AT1G78950.1 & Beta-amyrin synthase; Converts oxidosqualene to beta-amyrin \\
\hline CAS1 & AT2G07050.1 & $\begin{array}{c}\text { Cycloartenol synthase; Converts oxidosqualene to cycloartenol. } \\
\text { Involved in plastid biogenesis }\end{array}$ \\
\hline UGT73B3 & AT4G34131.1 & $\begin{array}{l}\text { UDP-glucosyl transferase } 73 \mathrm{~B} 3 \text {; Involved in stress or defense } \\
\text { responses }\end{array}$ \\
\hline SQS1 & AT4G34640.1 & Squalene synthase \\
\hline CYP93D1 & AT5G06900.1 & Member of CYP93D \\
\hline AT3G32047 & AT3G32047.1 & Cytochrome P450 superfamily protein \\
\hline CYP716A1 & AT5G36110.1 & Member of CYP716A \\
\hline
\end{tabular}




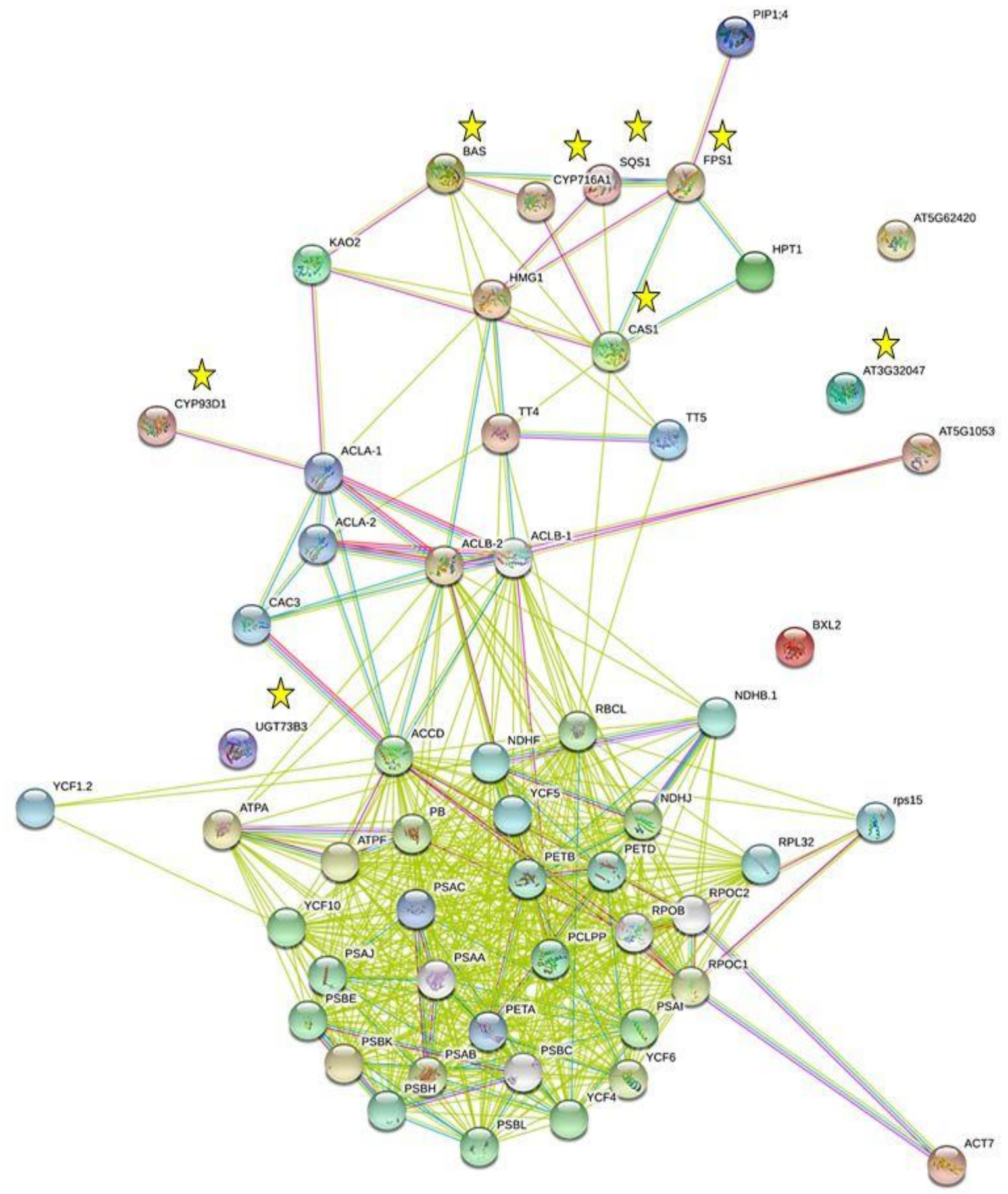

A. thaliana شكل r- شبكه زنى زنهاى مهم مسير سنتز كليسيريزين در شيرينبيان در مقابل زنوم

Figure 2. Gene network of genes involved in synthesis of glycyrrhizin against A. thaliana genome

نسبى هر جهار زن، تفاوت معنىدارى بين دو فصل پاييز و بهار در سطح ا درصد نشان دادند. نتايج نشان داد كه بركان فصل باييز در مقايسه با فصل بهار باعث افزايش در سطح

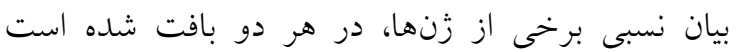

$$
\text { (شكل ع و 0). }
$$

qRT- اعتبارسنجى بيان زنها با استفاده از واكنش

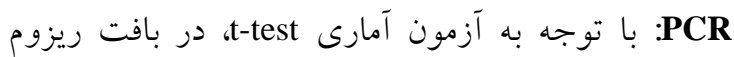
تغييرات بيان نسبى زن BAS، بين دو فصل جاييز و بهار

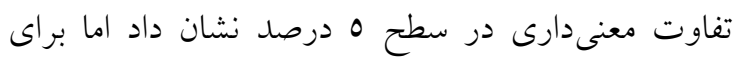

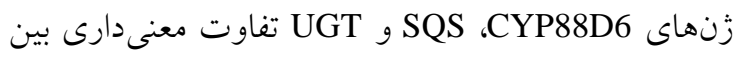
اين دو فصل مشاهده نشد. در بافت برى، تغييرات بيان 


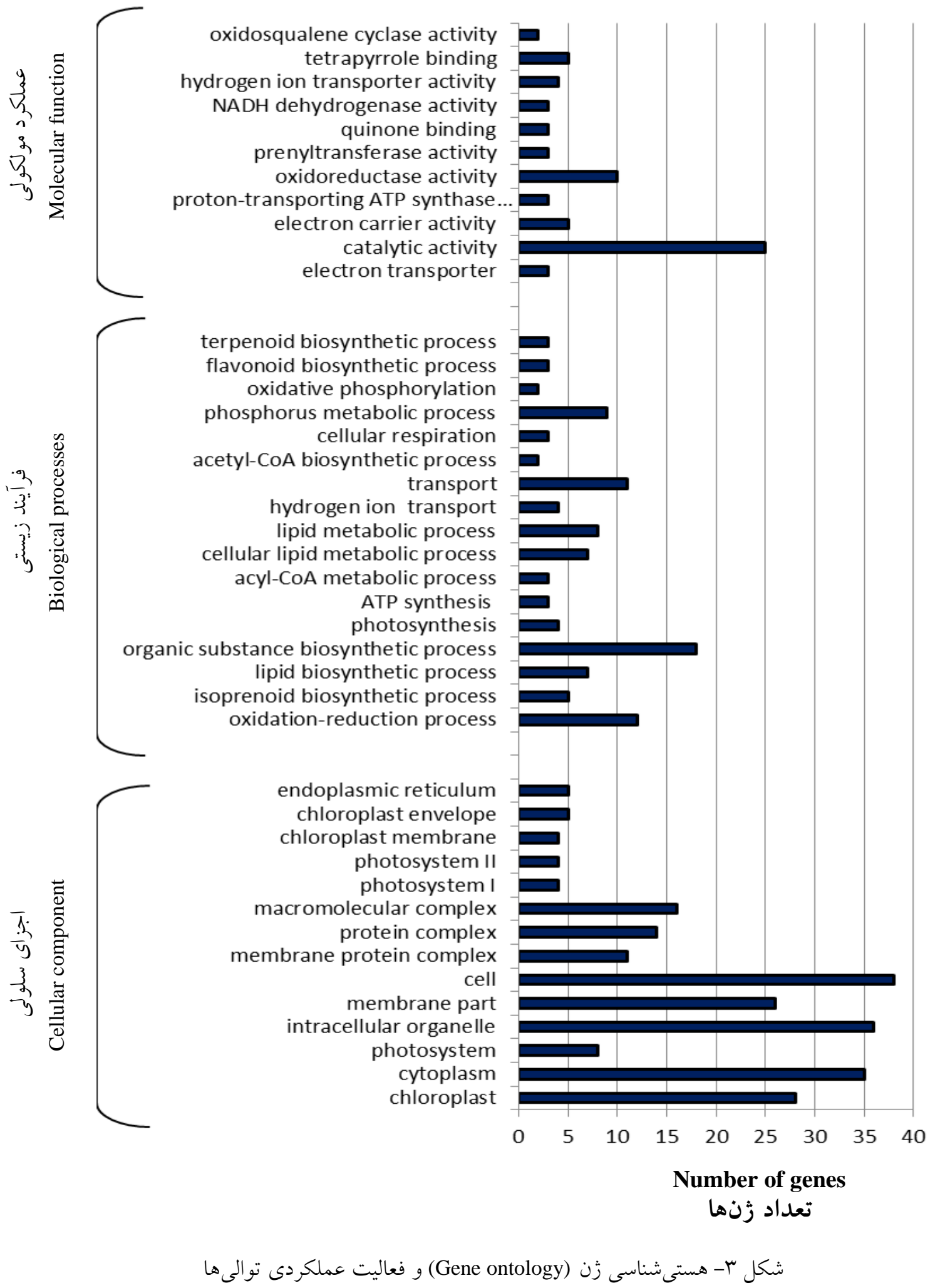

Figure 3. Gene ontology and functional activity of sequences 


$$
\text { جدول ع- نتايج تعيين نقطهى ايزوالكتريك (Pi)، وزن مولكولى (Mw) و مكانيابى سلولى توالى هاى بروتئينى مربوط به گونه }
$$

Table 4. Results of determination of isoelectric point $(\mathrm{Pi})$, molecular weight $(\mathrm{Mw})$ and cellular location of

\begin{tabular}{|c|c|c|c|c|}
\hline شماره دسترسى & $\begin{array}{c}\text { نام بروتئين } \\
\text { Protein name }\end{array}$ & $\begin{array}{c}\text { مكان سلولى } \\
\text { Cell location }\end{array}$ & $\begin{array}{c}\text { نقطه ايزوالكتريك } \\
\text { Pi }\end{array}$ & $\begin{array}{c}\text { وزن مولكولى } \\
\text { Mw }\end{array}$ \\
\hline AMR98504.1 & squalene synthase 1 & Endoplasmic reticulum & 8.18 & 47252.02 \\
\hline BAD08587.1 & lupeol synthase & Endoplasmic reticulum & 6.61 & 86688 \\
\hline BAA76902.1 & cycloartenol synthase & Endoplasmic reticulum & 6.35 & 86453.96 \\
\hline ARB43805.1 & beta-amyrin synthase & Endoplasmic reticulum & 6.19 & 87072.74 \\
\hline AKM97308.1 & cytochrome P450 88D6 & Endoplasmic reticulum & 8.51 & 56266.28 \\
\hline YP_009027303.1 & cytochrome b6/f complex & Extracellular & 6.56 & 17472.83 \\
\hline YP_009027302.1 & cytochrome b6 & Extracellular & 8.89 & 24126.47 \\
\hline AIN25418.1 & beta-amyrin 24-hydroxylase CYP93E6 & Plasma membrane & 8.7 & 57905.47 \\
\hline BAA89815.1 & beta-amyrin synthase & Endoplasmic reticulum & 6.13 & 87516.3 \\
\hline
\end{tabular}
protein sequences related to G. glabra

جدول 0- نتايج تعيين نقطهى ايزوالكتريك (Pi)، وزن مولكولى (Mw) و مكانيابى سلولى توالى هاى بروتئينى مربوط به كونه G. uralensis

Table 5. Results of determination of isoelectric point $(\mathrm{Pi})$, molecular weight $(\mathrm{Mw})$ and cellular location of

\begin{tabular}{|c|c|c|c|c|}
\hline شماره دسترسى & $\begin{array}{c}\text { نام يروتئين } \\
\text { Protein name }\end{array}$ & $\begin{array}{c}\text { مكان سلولى } \\
\text { Cell location }\end{array}$ & $\begin{array}{c}\text { نقطه ايزوالكتريك } \\
\text { Pi }\end{array}$ & $\begin{array}{c}\text { وزن مولكولى } \\
\text { Mw }\end{array}$ \\
\hline ADG36724.1 & squalene synthase 2 & Endoplasmic reticulum & 8.21 & 47084.66 \\
\hline ACV21067.1 & beta-amyrin synthase & Endoplasmic reticulum & 6.19 & 87026.69 \\
\hline BAW34647.1 & cytochrome P450 716A179 & Plasma membrane & 8.06 & 55285.2 \\
\hline ADE88148.1 & beta-amyrin synthase & Endoplasmic reticulum & 6.19 & 87072.74 \\
\hline ACS66750.1 & squalene synthase & Endoplasmic reticulum & 8.5 & 47276.08 \\
\hline ADE18771.1 & farnesyl-diphosphate synthase & Cytoplasmic & 5.56 & 39359.12 \\
\hline ARB43808.1 & beta-amyrin synthase & Endoplasmic reticulum & 6.13 & 87130.78 \\
\hline AAW73054.1 & cytochrome P450 & Endoplasmic reticulum & 4.7 & 4366.93 \\
\hline ANJ03631.1 & UDP-glycosyltransferase & Plasma membrane & 5.88 & 53868.89 \\
\hline BAL41371.1 & lupeol synthase & Endoplasmic reticulum & 6.61 & 86790.09 \\
\hline BAG68930.1 & cytochrome P450 monooxygenase & Plasma membrane & 8.78 & 58154.54 \\
\hline BAG68929.1 & cytochrome P450 88D6 & Endoplasmic reticulum & 8.62 & 56372.49 \\
\hline
\end{tabular}
protein sequences related to G. uralensis 


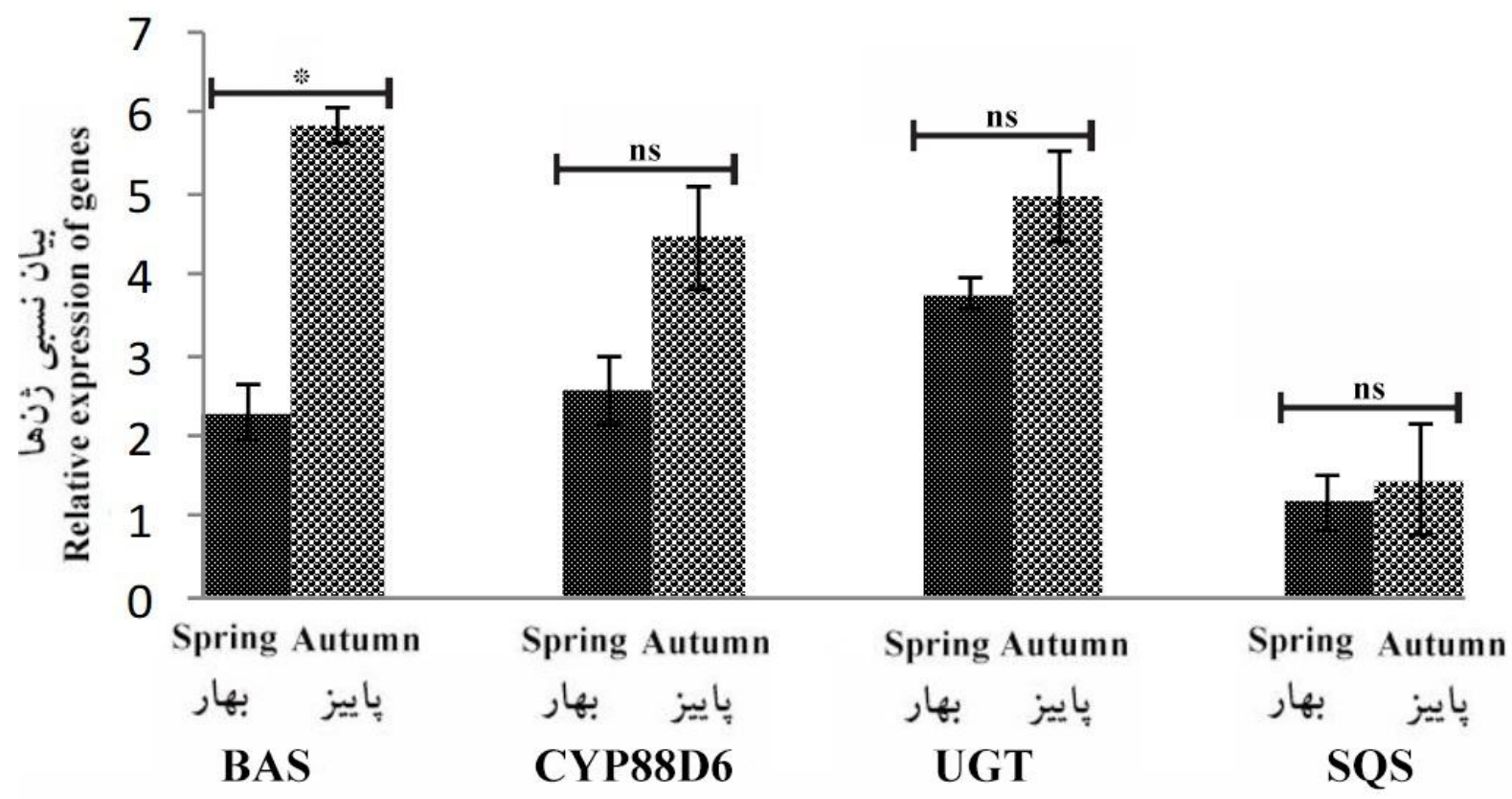

$$
\text { شكل ع- مقايسه تغييرات بيان زنها بين دو فصل ياييز و بهار مربوط به بافت ريزوم }
$$

Figure 4. Comparison of gene expression changes between autumn and spring seasons related to rhizome tissue ns

${ }^{\mathrm{ns}}$ and *: Non-significant and significant at $5 \%$ probability level, respectively

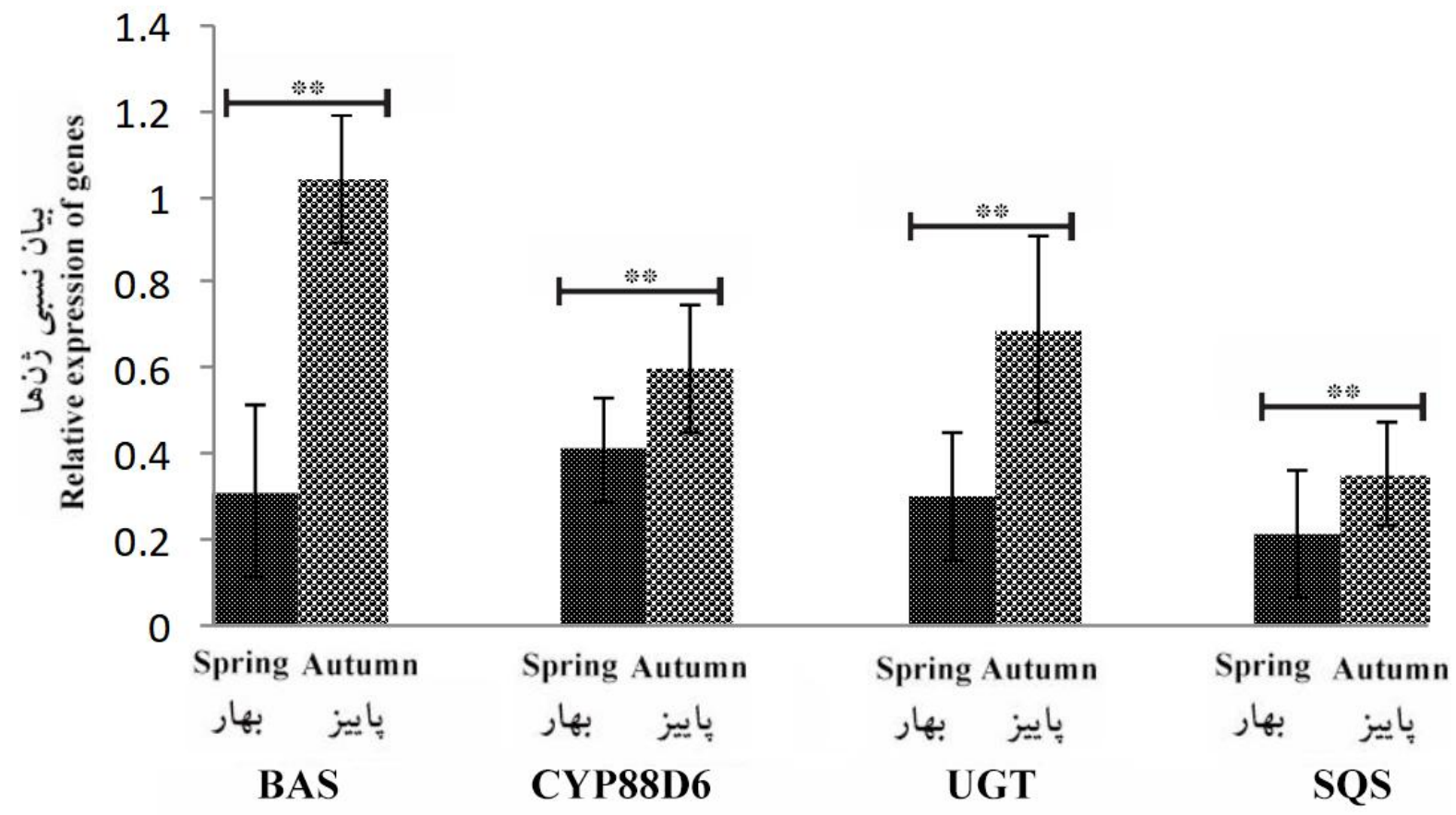

$$
\text { شكل 0- مقايسه تغييرات بيان زنها بين دو فصل ياييز و بهار مربوط به بافت برگ }
$$

Figure 5. Comparison of gene expression changes between autumn and spring seasons related to leaves tissue

$$
\text { : }
$$

**: Significant at $1 \%$ probability level 


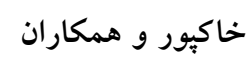

قرار دارد و در اكتبر و نوامبر بيان اين زن شروع به كاهش

كرد (Liu and Liu, 2012)

تغييرات اقليمى و فصول مختلف مى تواند بهطور اساسى

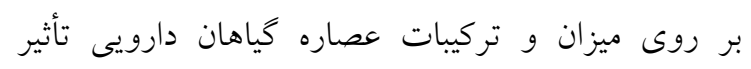

بحذارد. تحقيقات نشان داده است كه ميزان مواد مؤثره و

در راستاى آن بيان زنهاى توليد كننده آنها در اندامها و و

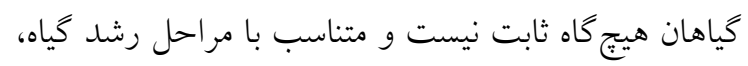

شرايط محيطى و فصلهاى مختلف قابل تغيير است.

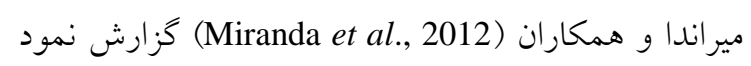

كه شرايط محيطى مانند ويزگ هاى اقليمى و تغييرات

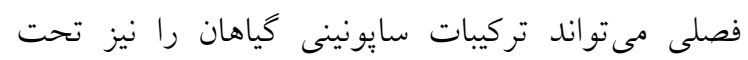

Somjen et al., ) تأثير قرار دهد. سومجن و همكارني

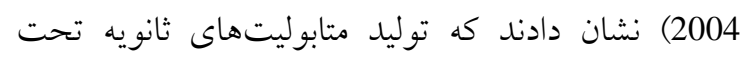

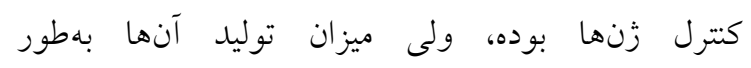

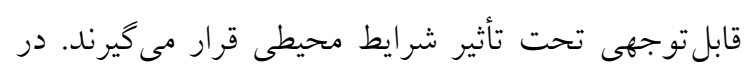

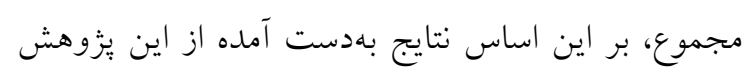

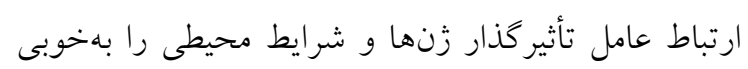

نشان مى دهد.

مطالعه بيوانفورماتيكى و بررسى الخوى بيان جِند زُن مهم دخيل ...

$$
\begin{aligned}
& \text { اين تفاوت در بيان نسبى زنها را مىتوان به روند توليد }
\end{aligned}
$$

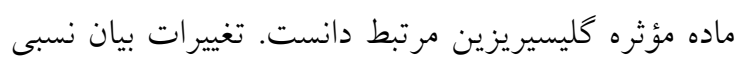

$$
\begin{aligned}
& \text { زنها در هر دو بافت بهصورت تنظيم مثبت بوده است و }
\end{aligned}
$$

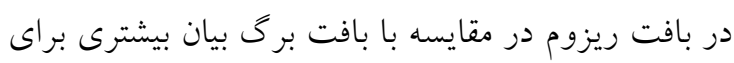

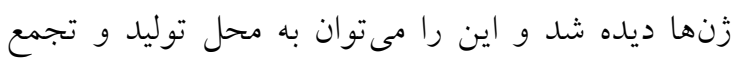

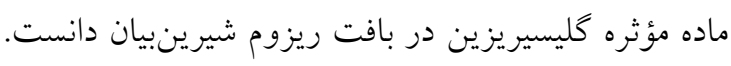

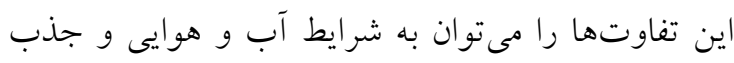

$$
\begin{aligned}
& \text { رطوبت نيز مرتبط دانست. هم جنين توليد مواد مؤثره در }
\end{aligned}
$$

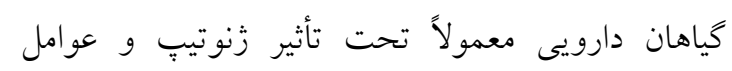

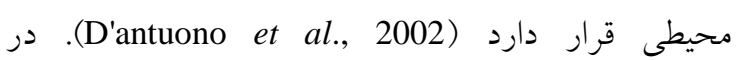

$$
\begin{aligned}
& \text { مطالعهاى با هدف اثر بافت و زمان نمونهبردارى بر روى درى }
\end{aligned}
$$

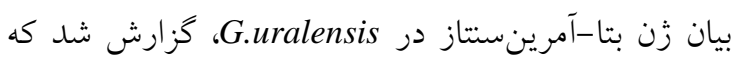

$$
\begin{aligned}
& \text { بخشهاى زيرزمينى در مقايسه با بخشهاى هوايى و }
\end{aligned}
$$

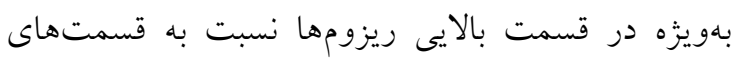

$$
\begin{aligned}
& \text { هايينى، افزايش در بيان اين زن ديده شده است. از نظر } \\
& \text { زمان نمونهبردارى، بيان زن BAS را مىتوان به جهار }
\end{aligned}
$$

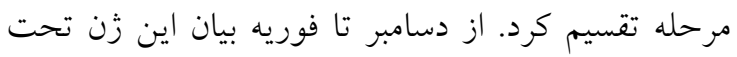

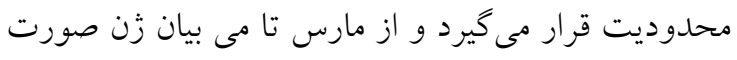

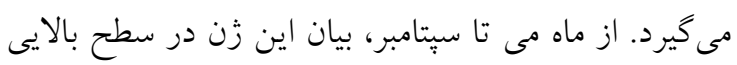

\section{References}

Aliakbari, M., Shamloo-Dashtpagerdi, R. and Ebrahimie, A. (2013). Bioinformatic analysis of saffron (Crocus sativus L.) stigma est sequences to determining functional genome orientation and gene network. Journal of Saffron Agronomy and Technology, (1)1: 40-45 (In Persian).

Bayati Zadeh, J., Moradi Kor, Z. and Karimi Goftar, M. (2013). Licorice (Glycyrrhiza glabra Linn) as a valuable medicinal plant. International Journal of Advanced Biological and Biomedical Research, 1(10): 1281-1288 (In Persian).

D'antuono, L.F., Moretti, A. and Lovato, A.F. (2002). Seed yield, yield components, oil content and essential oil content and composition of Nigella sativa l. and Nigella damascene l. Industrial Crops and Products, 15(1): 59-69.

Fukai, T., Sheng, C.B., Horikoshi, T. and Nomura, T. (1996). Isoprenylated flavonoids from underground parts of Glycyrrhiza glabra. Phytochemistry, 43(5): 1119-1124.

Hossein Panahi, Z.H., Maroufi, A. and Bahramnejad, B. (2016). Isolation and expression pattern of $\beta$-amyrin synthase in chicory (Cichorium intybus L.). Genetics Novin Journal, 3(11): 399-409 (In Persian).

Hosseinzadeh, H. and Nassiri- Asl, M. (2015). Pharmacological effects of Glycyrrhiza Spp. and its bioactive constituents: update and review. Phytotherapy Research, 29(12): 1868-1886 (In Persian).

Kim, D.W., Kim, R.N., Choi, S.H., Kim, D.W., Nam, S.H., Choi, H.S. and Kang, A. (2011). EST analysis predicts putatively causative genes underlying the pharmaceutical application of Glycyrrhiza uralensis fisch. Plant Molecular Biology Reporter, 29(4): 814-824.

Li, Y., Luo, H.M., Sun, C., Song, J.Y., Sun, Y.Z., Wu, Q. and Chen, S.L. (2010). EST analysis reveals putative genes involved in glycyrrhizin biosynthesis. Bmc Genomics, 11(1): 268. 
Liu, Y., and Liu, C.S. (2012). Study on the spatial and temporal expression of $\beta$-AS gene of Glycyrrhiza uralensis. Chin Mater Med, 35(4): 528-531.

Miranda, M., Vega-Gálvez, A., Quispefuentes, I., Rodríguez, M.J., Maureira, H. and Martínez, E.A. (2012). Nutritional aspects of six quinoa (Chenopodium quinoa Willd.) Ecotypes from three geographical areas of Chile. Chilean Journal of Agricultural Research, 72(2):175-181.

Mochida, K., Sakurai, T., Seki, H., Yoshida, T., Takahagi, K., Sawai, S., and Saito, K. (2017). Draft genome assembly and annotation of Glycyrrhiza uralensis, a medicinal legume. The Plant Journal, 89(2): 181-194.

Nasrollahi, V., Mirzaie-Asl, A., Piri, K., Nazeri, S. and Mehrabi, R. (2014). The effect of drought stress on the expression of key genes involved in the biosynthesis of triterpenoid saponins in liquorice (Glycyrrhiza glabra). Phytochemistry, 103: 32-37.

Ogata, Y. and Suzuki, H. (2011). Plant expressed sequence tags databases: practical uses and the improvement of their searches using network module analysis. Plant Biotechnology, 28(4): 351360.

Pandey, D.K. and Ayangla, N.W. (2017). Biotechnological aspects of the production of natural sweetener glycyrrhizin from Glycyrrhiza sp. Phytochemistry Reviews, 17: 1-34.

Rebhun, J.F., Glynn, K.M. and Missler, S.R. (2015). Identification of Glabridin as a bioactive compound in licorice (Glycyrrhiza glabra L.) extract that activates human peroxisome proliferatoractivated receptor gamma (Ppary). Fitoterapia, 106: 55-61.

Schmittgen, T.D. and Livak, K.J. (2008). Analyzing Real-time PCR data by the comparative $c_{t}$ method. Nature Protocols, 3(6): 1101-1108.

Seki, H., Ohyama, K., Sawai, S., Mizutani, M., Ohnishi, T., Sudo, H. and Muranaka, T. (2008). Licorice $\beta$-amyrin 11-oxidase, a cytochrome p450 with a key role in the biosynthesis of the triterpene sweetener glycyrrhizin. Proceedings of the National Academy of Sciences, 105(37): 14204-14209.

Seki, H., Tamura, K. and Muranaka, T. (2015). P450s and UGTs: key players in the structural diversity of triterpenoid saponins. Plant and Cell Physiology, 56(8): 1463-1471.

Shirazi, Z., Aalami, A., Tohidfar, M. and Sohani, M. (2017). Cloning, bioinformatics study and gene expression evaluation of squalene synthase 1 in Iranian native licorice. Genetic Engineering and Biosafety Journal, 1(6): 37-48 (In Persian).

Somjen, D., Knoll, E. and Vaya, J. (2004). Estrogen-like activity of licorice root constituents: glabridin and glabrene, in vascular tissues in vitro and in vivo. Journal of Steroid Biochemical Molecular Biology. 91: 147-155.

Tang, Z.H., Li, T., Tong, Y.G., Chen, X.J., Chen, X.P., Wang, Y.T. and Lu, J.J. (2015). A systematic review of the anticancer properties of compounds isolated from licorice (gancao). Planta Medica, 81(18): 1670-1687.

Wink, M. (2010). Introduction: biochemistry, physiology and ecological functions of secondary metabolites. Annual Plant Reviews, 40: 1-19.

Zarabi, M., Fardoe, R. and Maleki-Tabrizi, N. (2013). Principle of Bioinformatics. Ayiizh Publisher, Tehran, IR (In Persian).

Zhao, H., Tang, Q., Mo, C., Bai, L., Tu, D. and Ma, X. (2017). Cloning and characterization of squalene synthase and cycloartenol synthase from Siraitia grosvenorii. Acta Pharmaceutica Sinica $B, 7(2): 215-222$. 


\title{
Bioinformatics Study and Investigation of the Expression Pattern of Several Important Genes Involved in Glycyrrhizin Synthesis of Glycyrrhiza glabra L. in Autumn and Spring Seasons
}

\author{
Atefeh Khakpour ${ }^{1}$, Maryam Zolfaghari ${ }^{2, *}$ and Karim Sorkheh ${ }^{3}$
}

1- M.Sc. Student, Department of Horticultural Sciences, Faculty of Agriculture, Shahid Chamran University of Ahvaz, Ahvaz, Iran

2- Assistant Professor, Department of Horticultural Sciences, Faculty of Agriculture, Shahid Chamran University of Ahvaz, Ahvaz, Iran

3- Assistant Professor, Department of Agronomy and Plant Breeding, Shahid Chamran University of Ahvaz, Ahvaz, Iran

(Received: July 3, 2018 - Accepted: December 8, 2018)

\begin{abstract}
Glycyrrhiza is one of the important medicinal plants that is in danger of extinction. Search for finding accessions that have a higher glycyrrhizic acid is very important in breeding programs. Functional genomics methods such as EST sequencing prepare the ability to identify consensus gene families among studied species and interpretation of the genome. In this research, 55960 EST sequences of two different species of this plant along with the protein sequences were analyzed in order to identify the molecular aspects and functional analysis of the genome and the gene network involved in the biosynthesis of glycyrrhizin. Also, in order to validation of results, relative expression of four important genes in the pathway of glycyrrhizin biosynthesis including squalene synthase (SQS), $\beta$ amyrin synthase (BAS), $\beta$-amyrin 11-oxidase (CYP88D6) and UDP-glucuronyl transferase (UGT) were evaluated. After trimming and qualitative evaluation the sequences, 6427 contig sequences and 30895 singleton (37322 unigene) were generated, which covered a total of $26884666 \mathrm{bp}(7.06 \%)$ of the licorice genome. Genome functional activity showed that most genes play a role in the catalytic activity and cellular and metabolic processes in which these genes interact within cells and intracellular organels. Locating this group of genes showed that the genes involved in glycyrrhizin biosynthesis pathway were localized in endoplasmic reticulum. Results of validation using qRT-PCR showed that in the autumn and in the rhizome tissue, the genes of BAS, CYP88D6, UGT and SQS were up-regulated. The results of this study can be valuable for genomic sequencing, functional groups, genetic diversity and functional genomics of this plant.
\end{abstract}

Keywords: Functional genome, Gene network, Licorice, Glycyrrhizin, qRT-PCR

*Corresponding Author, E-mail: m.zolfaghari@scu.ac.ir 